\title{
The food-print of Paris: long-term reconstruction of the nitrogen flows imported into the city from its rural hinterland
}

\author{
Gilles Billen · Sabine Barles · Josette Garnier • \\ Joséphine Rouillard · Paul Benoit
}

Received: 8 April 2008/Accepted: 24 June 2008/Published online: 22 July 2008

(C) The Author(s) 2008

\begin{abstract}
Between the tenth and twentieth century the population of Paris city increased from a few thousand to near 10 million inhabitants. In response to the growing urban demand during this period, the agrarian systems of the surrounding rural areas tremendously increased their potential for commercial export of agricultural products, made possible by a surplus of agricultural production over local consumption by humans and livestock in these areas. Expressed in terms of nitrogen, the potential for export increased from about $60 \mathrm{~kg} \mathrm{~N} / \mathrm{km}^{2} /$ year of rural territory in the Middle Ages, to more than 5,000 kg N/ $/ \mathrm{km}^{2} /$ year from modern agriculture. As a result of the balance between urban population growth and rural productivity, the rural area required to supply Paris (i.e. its food-print) did not change substantially for several centuries, remaining at the size of the Seine watershed surrounding the city (around $60,000 \mathrm{~km}^{2}$ ). The theoretical estimate of the size of the supplying hinterland at the end of the eighteenth century is confirmed by the figures deduced from the analysis of the historical city toll data (octroi). During the second half of the twentieth century, the 'food-print' of Paris reduced in size, owing to an unprecedented increase in the potential
\end{abstract}

G. Billen $(\bowtie) \cdot$ J. Garnier $\cdot$ J. Rouillard

UMR Sisyphe, Centre National de la Recherche

Scientifique-Université Pierre et Marie Curie,

4 Place Jussieu, 75005 Paris, France

e-mail: gilles.billen@upmc.fr

\section{S. Barles}

Laboratoire Théorie des Mutations Urbaines, UMR CNRS AUS 7136, 4, Rue Alfred Nobel, Cité Descartes 77420Champs-sur-Marne, France

\section{P. Benoit}

Equipe d'Histoire des Techniques, LAMOP-UMR 8589,

Université de Paris 1 Panthéon-Sorbonne, Paris, France for commercial export associated with modern agricultural systems based on chemical $\mathrm{N}$ fertilization. We argue that analysing the capacity of territories to satisfy the demand for nitrogen-containing food products of local or distant urban population and markets might provide new and useful insights when assessing world food resource allocation in the context of increasing population and urbanization.

Keywords Paris - Seine basin - Ecological footprint . Food-print $\cdot$ Nitrogen $\cdot$ Autotrophy/heterotrophy

\section{Introduction}

A city can be defined as a grouping of population which does not produce its own means of food subsistence (Asher 2001). It therefore depends upon surrounding rural areas for the provision of food resources, as well as fiber, fuel, and building materials. In a work often considered to have laid the basis of economic geography, Von Thünen (1826) deduced from an idealized economic model based on early nineteenth century agriculture and transport costs, that a city would tend to be surrounded by several concentric rings of farming activity, beginning with market gardening and dairy farming, followed by forestry, cereal production, and finally cattle breeding. In the present day, cheap transportation, preservation techniques and the opening of the global market economy have considerably scattered the distribution of agricultural areas that supply food to cities, but have certainly not reduced the dependence of cities on such regions, wherever they are located, nor the pressure exerted on the latter by urban markets. Wakernagel and Rees (1996) introduced the concept of the ecological footprint which provides an account of the total area of 
productive surfaces required to produce, under prevailing world technology, the resources consumed by a country or a city. Feeding modern cities is associated with one-third to half of the global ecological footprint, ranging world-wide from 0.8 to 3.8 global-hectares per inhabitant (WWF 2002). This simple "footprint" indicator, however, fails to fully describe the complexity of the relationships that a city establishes with its rural hinterland for the supply of food, nor how, over time, these relationships impact upon the development of both the city and the countryside.

Our goal here is to examine how the city of Paris has grown up in parallel with the development of its surrounding rural landscape over the long time scale of the last Millennium. In particular, we analyse (1) how closely dependent the past development of the city has been on the progress and specialization of agriculture in the Parisian basin, as well as (2) the importance of the growing urban food demand on the development and spatial distribution of farming practices in the surrounding rural regions. For this purpose, we have collated available information allowing a comparison of changes in the food requirement of the growing urban population and in the potential for commercial export of the Seine basin rural territory throughout a period beginning around the tenth century to the present day. Our approach is based on historical biogeochemistry. Since nitrogen is an essential constituent of the human diet as well as the most limiting factor in agricultural production in temperate regions, we elected to describe the exchanges between the countryside and the city in terms of nitrogen flows. Our analysis thus contributes to a better description and understanding of the profound alterations to the global nitrogen cycle caused by human development (Galloway et al. 1995; Galloway and Cowling 2002). As underlined by Smil (1999), agricultural production is by far the largest cause of the doubling in the amount of reactive nitrogen entering the biospheric cycle compared to preindustrial conditions. This process, operating through enhanced biological $\mathrm{N}_{2}$ fixation and industrial $\mathrm{N}$ fertilizer production, has resulted in several environmental dysfunctions (Galloway et al. 1995; Galloway and Cowling 2002). Today, more than half of the crops produced in rural areas of the world are consumed in urban zones, which set important constraints on the mode of agricultural production at both the regional and global scales.

\section{Sources and methods}

Estimating the flux of material between a city and its hinterland over a millennium obviously requires a large diversity of sources as well a close interdisciplinary collaboration. Paris and the rural areas of the Parisian basin have been the subject of an extensive historical literature, including excellent reviews, which provide the required historical background knowledge necessary to the approach described in this report. Among the sources available, a number of studies have been particularly useful. Favier (1997) published a synthesis of two Millennia of Parisian history while, concerning the Middle Ages and the Modern Epoch, the works by Fourquin (1956), Jacquart (1974) and Goubert (1982) were quite useful. The recent works of Kaplan (1988) and Abad (2002) additionally provided an extremely detailed analysis of the food supply of Paris at the end of the eighteenth century. Barles $(2005,2007)$ and Barles and Lestel (2007) closely analysed the food consumption and nitrogen metabolism of Paris during the nineteenth century while, from a more general perspective, authors such as Mazoyer and Roudart (1998) with their socio-ecological analysis of agrarian systems, opened the way to the historical-biogeochemical approach we developed here in the case of the Parisian basin. The principles and methods of material flow analysis and spatial imprint evaluation have been described in detail and applied to the special case of Linköping (Sweden) for the period 1870 2000 by Schmid-Neset (2005).

As stated earlier, our approach consists of comparing, in terms of nitrogen flows, the food demand for consumption in the city with the ability of the surrounding rural territories to meet that demand through commercial export. We used conversion factors compiled from various sources to convert data expressed in specific physical units into nitrogen (Table 1).

\section{Population and food requirement of Paris}

Paris conurbation presently numbers $9,650,000$ inhabitants if only the contiguous urban area is considered, or $11,175,000$ inhabitants if the whole metropolitan area is taken into account (INSEE 2006). The figure for intra muros Paris is 2,125,800 (INSEE 2006). After the early eleventh century, when the population of Paris was estimated to be only a few thousand inhabitants (Favier 1997), a period of rapid population growth occurred, linked to the status of capital city conferred to Paris under the reign of Philippe Auguste (1180-1223). This population expansion continued until the early fourteenth century when it reached 200,000 capita (Fig. 1). A century of crisis then followed in which war and plague severely decreased the population of both the city and the rural regions (Bois 1981; Jacquart 1974), but the urban population growth resumed at the beginning of the fifteenth century. It decreased again in the period 1562-1598 (French Wars of Religion), then increased continuously until Paris numbered more than 600,000 inhabitants at the time of the 1789 French Revolution. A fivefold increase then occurred 
Table 1 Nitrogen content of food and agricultural products (in $\%$ fresh weight of the cropped or consumed product), and other figures related to nitrogen flows in agrarian systems. (Compiled from Baccini and Bruner 1991; Soltner 2005; Smil 1999)

\begin{tabular}{|c|c|}
\hline Product & $\mathrm{N}$ content, $\%$ \\
\hline \multicolumn{2}{|l|}{ Foodstuff } \\
\hline Cereals & 1.8 \\
\hline Bread & 1.4 \\
\hline Potatoes & 0.3 \\
\hline Fresh vegetables and fruits & 0.4 \\
\hline Dry vegetables & 2.1 \\
\hline Meat & 3.4 \\
\hline Fish and seafood & 3.4 \\
\hline Eggs & 2.1 \\
\hline Milk & 0.5 \\
\hline Cheese & 3.7 \\
\hline Butter & 0.14 \\
\hline Beer & 0.05 \\
\hline Wine & 0.035 \\
\hline \multicolumn{2}{|l|}{ Feedstuff } \\
\hline Hay & 1.3 \\
\hline Straw & 0.5 \\
\hline Firewood & 0.2 \\
\hline \multicolumn{2}{|l|}{ Cultivated plants } \\
\hline Colza & 3.7 \\
\hline Sunflower & 3.5 \\
\hline Beet & 1.5 \\
\hline Livestock feed requirement & $\mathrm{kg} \mathrm{N} /$ capita/year \\
\hline Cattle & 95 \\
\hline Pigs & 6.5 \\
\hline Sheep and goats & 5.5 \\
\hline Horses & 45 \\
\hline Poultry & 0.3 \\
\hline Rabbits & 0.3 \\
\hline
\end{tabular}

during the nineteenth century, followed by a further doubling during the twentieth century.

On the wider scale, the city accounted for less than $5 \%$ of the total population of the Seine river watershed (about
$60,000 \mathrm{~km}^{2}$ surrounding Paris; Fig. 1) in the thirteen century, but reached $20 \%$ at the end of the eighteenth century. From that time on, growth has been restricted to the urban population (Fig. 1), which today represents $85 \%$ of the population of the watershed area.

The present per capita domestic food consumption can be evaluated by two kinds of statistical inquiries based on: (1) a record of the effective individual diet of a sample of the population (sample method) and (2) the balance of national production comparing import and export of food products (balance method). The latter method provides significantly higher figures than the former since it includes a number of losses during food storage, preparation and commercialisation. Thus, Table 2 shows that the gross per capita $\mathrm{N}$-food consumption in France (balance method) increased from 15 to $22 \mathrm{~g} \mathrm{~N} /$ day between 1950 and 2000, while the effective per capita consumption based on the INSEE enquiries (sample method) varied only slightly around a figure of $12 \mathrm{~g} \mathrm{~N} / \mathrm{capita} / \mathrm{day}$ from 1970 to 1990 (INSEE 1995). The latter figures, however, might be underestimated as they do not take into account food consumed outside of the home which represents an increasing part of the diet. It is worth noting that the mean per capita rate of nitrogen excretion calculated from wastewater analysis lies between 11 and $15 \mathrm{~g} \mathrm{~N} /$ capita/day (Servais et al. 1999; Garnier et al. 2006).

For historical periods, only the balance method is applicable. In the case of Paris, this process is facilitated by the fact that, until World War II, most goods entering the city were subject to a city toll (octroi), the statistics of which are available from the end of the eighteenth century (Feugère 1904). Barles (2007) analysed the available data from 1801 to 1914 and the data from the eighteenth century, including those already compiled by Lavoisier (Philippe 1961), were discussed by Abad (2002) (Table 2). Hay and other feed for horses were an important component of the city's demand for agricultural products. Barles (2007) has evaluated the extent of their import in the nineteenth century which subsequently becomes negligible in the second half of the twentieth century. Firewood for heating, cooking and baking must also be taken into account, the annual demand for which was estimated as
Fig. 1 Population growth in the Paris conurbation and in the Seine basin area during the last millennium. Synthesis of data compiled by Fourquin (1956); Croze (1988); Levasseur (1889); Favier (1997); Barles (2007); INSEE (2007); Dupeux (1981)
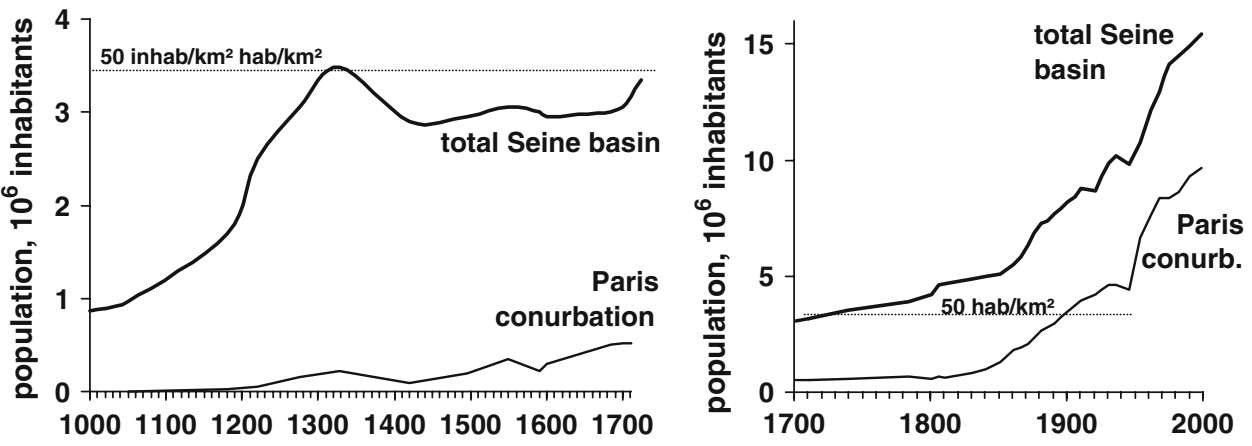
Table 2 Paris per capita consumption rate of nitrogen in food, feed and firewood from the ninenteenth to the twentieth century. estimated (1) from 1785 to 1889 from the data of Paris city toll statistics and (2) from 1950 to 2000 from the data of national French domestic consumption (INSEE 2000)

\begin{tabular}{|c|c|c|c|c|c|c|c|c|c|c|}
\hline & 1785 & 1820 & 1854 & 1889 & 1950 & 1960 & 1970 & 1980 & 1990 & 2000 \\
\hline \multicolumn{11}{|l|}{ Human food, kg N/capita/year } \\
\hline Bread and other cereal products & 2.26 & 2.57 & 2.52 & 2.04 & 1.94 & 1.69 & 1.48 & 1.42 & 1.38 & 1.34 \\
\hline Potatoes & 0.00 & 0.10 & 0.07 & 0.09 & 0.46 & 0.38 & 0.38 & 0.27 & 0.19 & 0.56 \\
\hline Fresh vegetables and fruits & 0.20 & 0.20 & 0.76 & 0.20 & 0.28 & 0.38 & 0.48 & 0.50 & 0.54 & 0.56 \\
\hline Dry vegetables & 0.01 & 0.65 & 0.15 & 0.00 & 0.07 & 0.07 & 0.05 & 0.04 & 0.03 & 0.03 \\
\hline Meat & 1.32 & 1.77 & 1.50 & 3.13 & 1.51 & 2.06 & 2.42 & 2.92 & 3.09 & 2.98 \\
\hline Fish and seafood & 0.35 & 0.27 & 0.37 & 0.21 & 0.36 & 0.47 & 0.52 & 0.62 & 0.80 & 0.78 \\
\hline Milk, cheese, eggs & 0.39 & 0.50 & 0.67 & 0.72 & 0.88 & 1.01 & 1.16 & 1.36 & 1.52 & 1.88 \\
\hline Wine, beer, cider, etc. & 0.06 & 0.03 & 0.04 & 0.08 & 0.07 & 0.08 & 0.06 & 0.06 & 0.05 & 0.04 \\
\hline Total, kg N/capita/year & 4.59 & 6.09 & 6.10 & 6.48 & 5.55 & 6.13 & 6.56 & 7.18 & 7.60 & 8.17 \\
\hline gN/capita/day & 12.6 & 16.7 & 16.7 & 17.7 & 15.2 & 16.8 & 18.0 & 19.7 & 20.8 & 22.4 \\
\hline \multicolumn{11}{|l|}{ Animal feed } \\
\hline kg N/capita/year & 1.7 & 2.1 & 1.3 & 2.3 & & & & & & \\
\hline gN/capita/day & 4.7 & 5.8 & 3.7 & 6.4 & & & & & & \\
\hline \multicolumn{11}{|l|}{ Firewood } \\
\hline kg N/capita/year & 1.46 & 1.54 & 0.54 & 0.24 & & & & & & \\
\hline gN/capita/day & 4.0 & 4.2 & 1.5 & 0.6 & & & & & & \\
\hline Total, kg N/capita/year & 7.77 & 9.76 & 7.97 & 9.05 & 5.55 & 6.13 & 6.56 & 7.18 & 7.60 & 8.17 \\
\hline gN/capita/day & 21.3 & 26.8 & 21.8 & 24.8 & 15.2 & 16.8 & 18.0 & 19.7 & 20.8 & 22.4 \\
\hline
\end{tabular}

1 stere per capita in the sixteenth century (Woronoff 2002) and 3 steres at the end of the eighteenth century (Rezé 2002; Benoit et al. 2004), before decreasing in proportion to substitution by coal.

Figure 2 reveals the long-term historical trends in the total nitrogen requirements for food, feed, and firewood of Paris during the last three centuries. For the purposes of our study, we will use the figures from the eighteenth century to estimate requirements in the earlier periods which lack

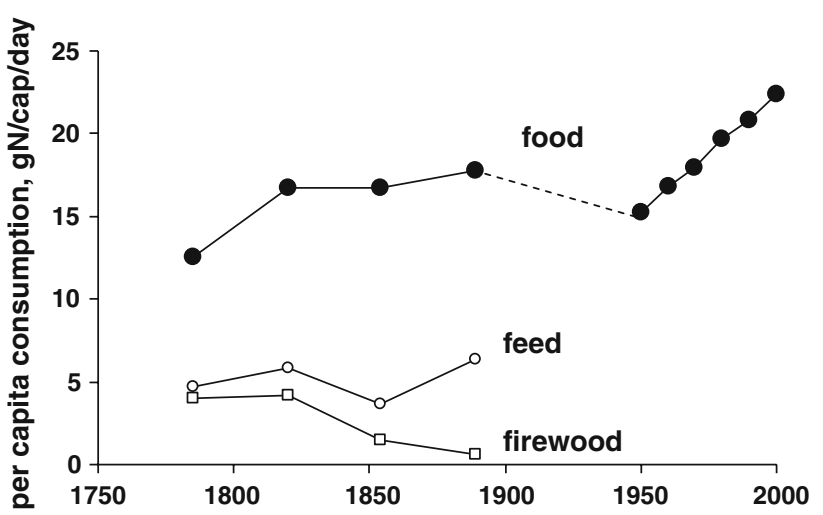

Fig. 2 Per capita food, feed and firewood requirements of Paris city, expressed in terms of nitrogen, estimated (1) from 1785 to 1889 from the data of Paris city toll statistics and (2) from 1950 to 2000 from the data of national French domestic consumption (INSEE 1995) direct data, which, as far as food is concerned, are close to the physiological survival diet of $10 \mathrm{~g} \mathrm{~N} / \mathrm{cap} /$ day.

\section{The potential for commercial export from the rural Parisian basin}

The potential for commercial export of agricultural products from a given territory represents the surplus of sustainable agricultural production over the requirements of the rural population. It depends on the technical and social organization of farming activities within the territory and on the capacity of the different components of the landscape mosaic to durably remobilize and return to the fields the amounts of nutrients exported with the crop. As far as nitrogen is concerned and before the advent of the industrial Haber-Bosch process, the latter is mainly dependent on biological $\mathrm{N}_{2}$ fixation in semi-natural systems.

For example, in slash-and-burn shifting cultivation agriculture, the capacity of the forest during a long fallow period to reconstitute the pool of nutrients exported with the crop from the temporarily cultivated plot is the key to the sustainability of the system. Typically, a farming family of 5 people, with neither mechanical nor animal traction, can exploit a shifting plot of one ha giving a yield of $1,000 \mathrm{~kg}$ grain equivalent per ha $(18 \mathrm{~kg} \mathrm{~N} / \mathrm{ha} /$ year $)$ and 
just providing the required annual ration of $200 \mathrm{~kg}$ grain per capita (Mazoyer and Roudart 1998). With a typical cultivation-fallow cycle of $1 / 30$ years, the sustainable population over the entire territory is 5 inhabitants over 30 ha or about 15 inhab. $/ \mathrm{km}^{2}$ (Fig. 3a; Table 3). The system, however, is barely able to release any surplus to be exported outside of the community.

Following the same line of reasoning, the livestock farming agricultural system which prevailed in Europe before the agricultural revolution of the Middle Ages (with slash-and-burn agriculture remaining by places) is characterized by the use of livestock grazing on grassland and to some extent in woodland during the day, to provide manure to arable land during its fallow period, where it spent the night. This allows to raise a cereals crop on the next year with a yield of about $250 \mathrm{~kg} / \mathrm{ha}$. This system, typically based on 5 persons farms exploiting 8 ha arable land undergoing biennial rotation, a livestock of 3 cattle units grazing on 18 ha grassland and 5 ha woodland, is able to sustain a rural population of about 16 inhabitant $/ \mathrm{km}^{2}$, without producing any surplus to be commercially exported (Fig. 3b; Table 3).

The agrarian system of the Middle Ages, which emerged in Western Europe as soon as the eighth century and became widespread during the eleventh and twelfth centuries (Contamine et al. 2003) represents from that respect a turning point. It can be similarly described at the level of a representative rural district or 'finage' (Benoit et al. 2002). The assumption is made of a community of 300 inhabitants, exploiting an area of 725 ha comprising 300 ha of arable land, 175 ha of grassland and 250 ha of woodland, and raising 100 large livestock units. Animal housing allowed to increase the rate of manure recovery, allowing an input of about $8 \mathrm{~kg} \mathrm{~N} / \mathrm{ha} /$ year over the
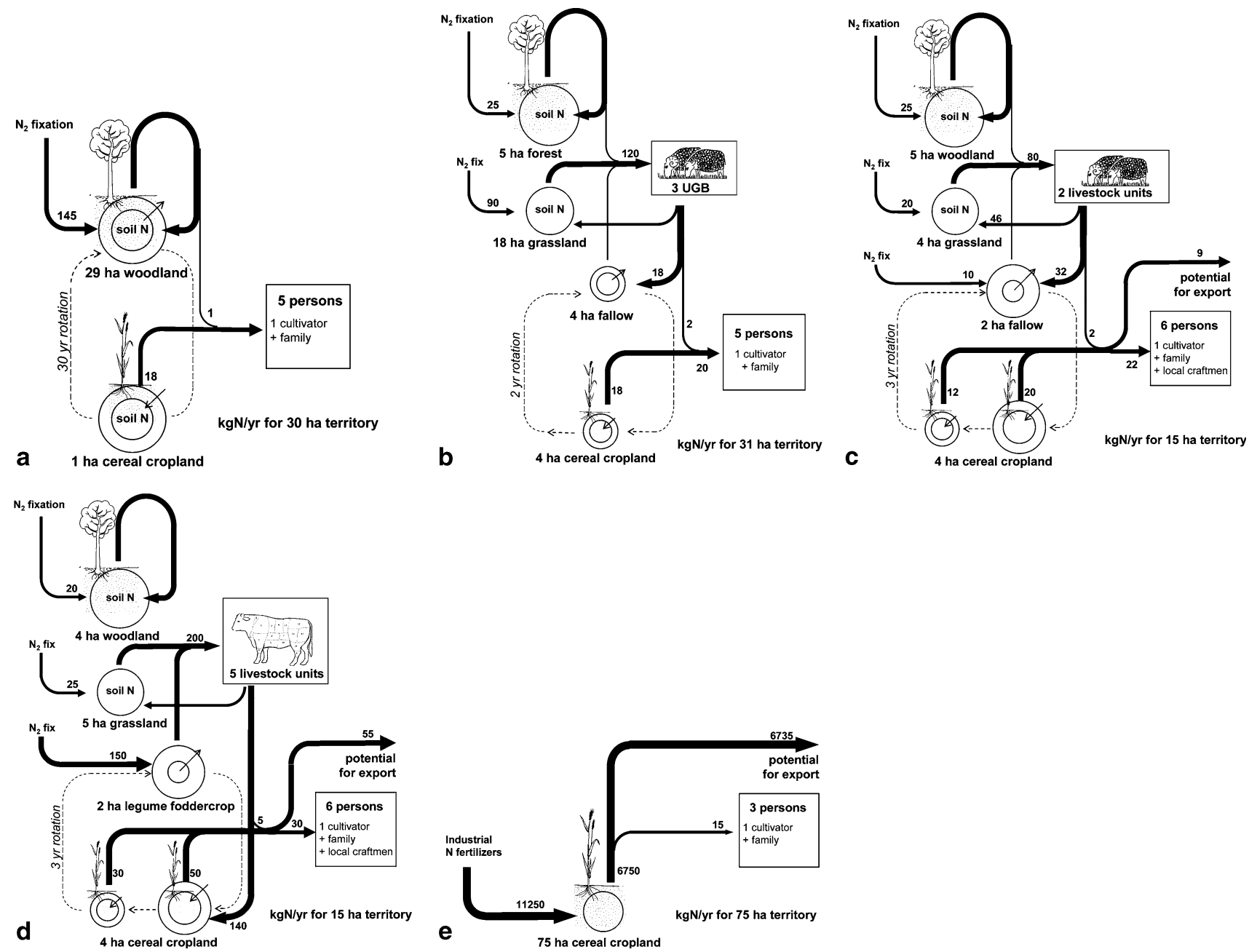

Fig. 3 Description of the nitrogen flows within different western European agrarian systems. The figures are given for a typical family farm (3-6 persons) and the associated land areas. a. Slash-and-burn shifting agriculture. b Pre-medieval agriculture/cattle farming system based on biennial crop-fallow rotation. c Medieval agriculture/cattle farming system based on triennial crop rotation with fallow, as used in small village communities. d Nineteenth century agriculture/cattle farming system based on triennial crop rotation with fallow replaced by a $\mathrm{N}_{2}$ fixing forage crop. e Mechanized modern cereal cultivation based on chemical fertilization 


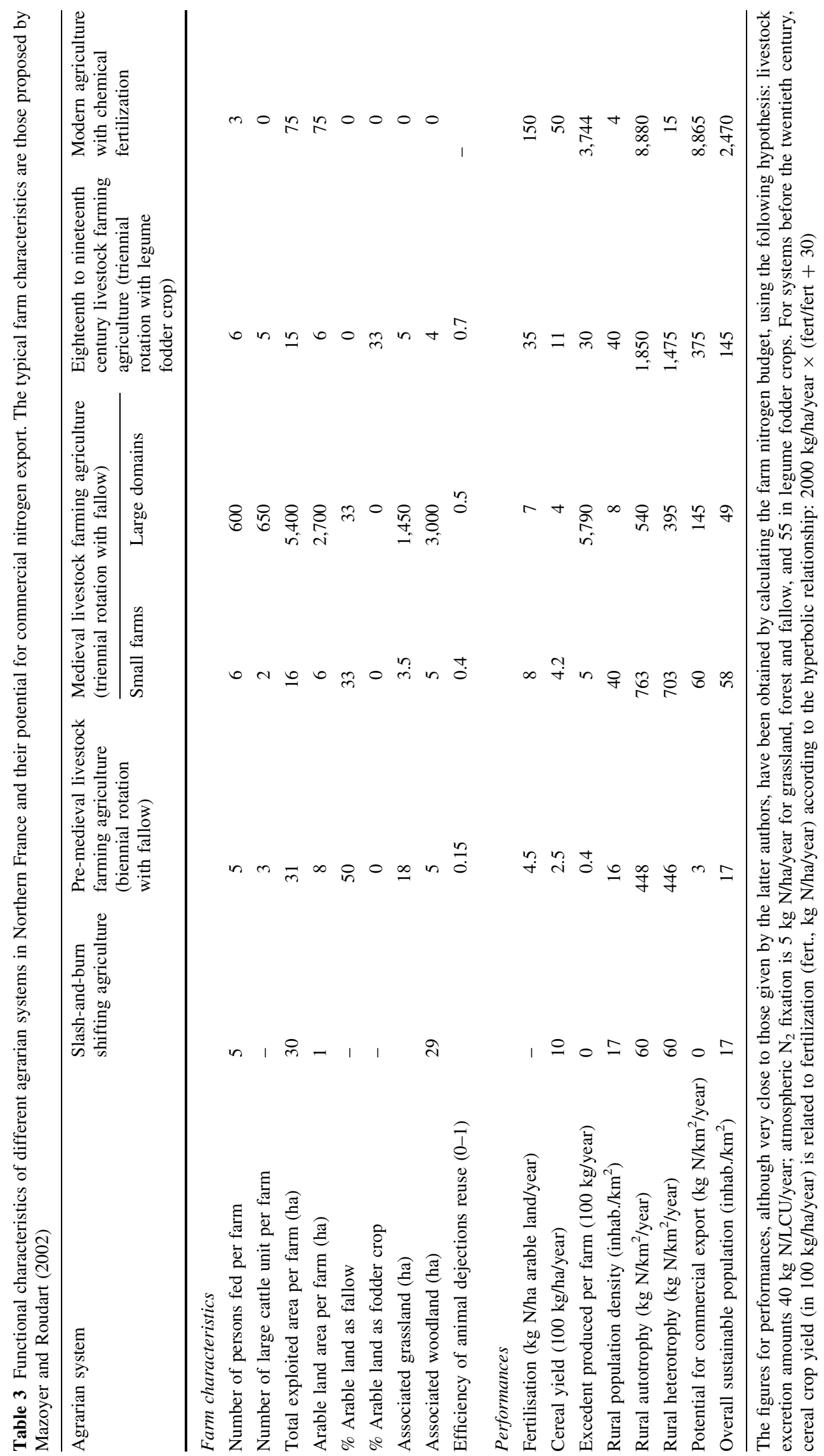




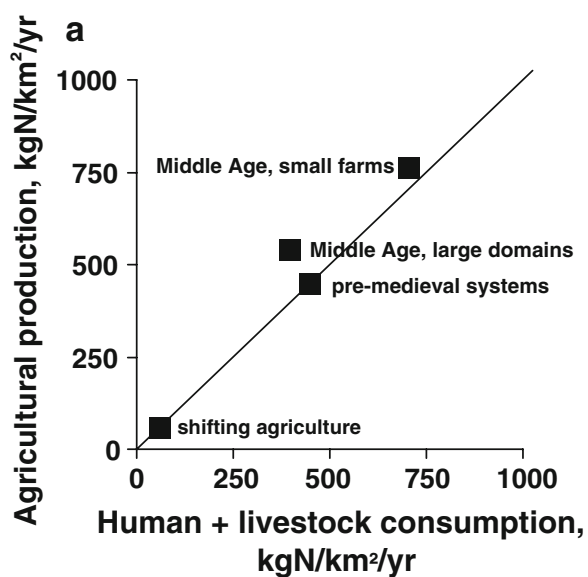

Fig. 4 Autotrophy versus heterotrophy diagram of the agrarian systems of the Paris basin since the tenth century. The total (vegetal) production of agriculture is plotted against the consumption by the local rural population and livestock. Systems located on the diagonal are self-sustaining. Those above the diagonal are autotrophic: their potential for commercial export of $\mathrm{N}$ is the difference between production and total local consumption. a. Slash-and-burn shifting agriculture; pre-medieval system with biennial rotation; traditional agrarian system of the Middle Ages with triennial rotation; agrarian

cultivated land area, yielding around $420 \mathrm{~kg}$ cereals/ha/ year, while the corresponding $\mathrm{N}$ export from grassland is easily compensated by the process of atmospheric $\mathrm{N}_{2}$ fixation at a rate of $5 \mathrm{~kg} \mathrm{~N} / \mathrm{ha} / \mathrm{year}$. In this way, not only is the rural population of close to 40 inhab. $/ \mathrm{km}^{2}$ fed but a sustainable surplus of about $60 \mathrm{~kg} \mathrm{~N} / \mathrm{km}^{2} /$ year is available for commercial export outside of the community (Fig. 3c; Table 3). Thus, the agrarian system of the Middle Ages is not only more productive than the preceding agricultural systems but it also has a clear autotrophic character, in the sense that agricultural primary production exceeds consumption by the local population and livestock (Le Thi Phuong et al. 2005) (Fig. 4a).

An analysis of the functioning of large ecclesiastical and lay domains in the fifteenth and sixteenth centuries (Benoit et al. 2002) shows that many were organized in a more extensive manner than peasant farms, with a higher animal loading, resulting in a lower human population density (often below 10 inhab. $/ \mathrm{km}^{2}$ ), but a potential for commercial export well over $100 \mathrm{~kg} \mathrm{~N} / \mathrm{km}^{2} /$ year (Table 3). Ironically, these estates created to meet an autarkic ideal, soon evolved towards commercial enterprises, exporting a much larger share of their internal production than the surrounding rural territories, and thus representing more autotrophic systems (Fig. 4a).

Except for certain large ecclesiastical or lay domains, the agrarian system based on a triennial rotation with fallow did not changed significantly in Northern France until the end of the eighteenth century. At that time, a trend emerged in which fallow was replaced by a $\mathrm{N}_{2}$ fixing

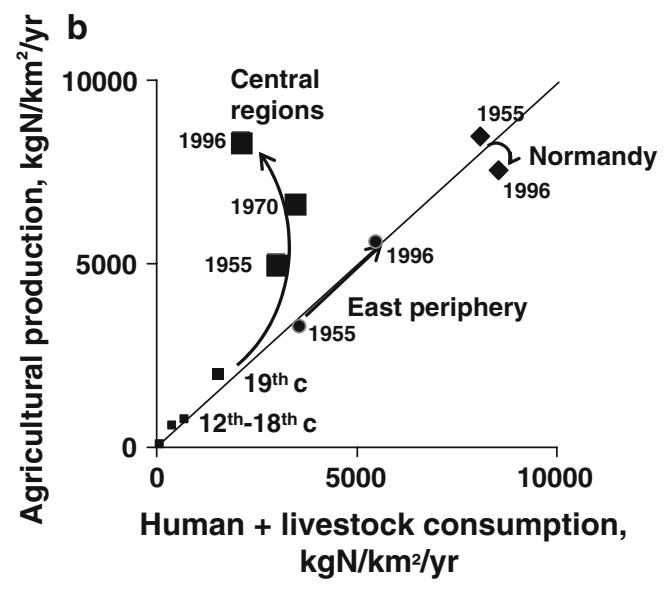

system of the large monastic or seignorial domains. b. Variations in autotrophy versus heterotrophy of the agrarian system of the central and peripheral regions of the Paris basin during the twentieth century. Central regions comprise the French "départements" of Aisne, Marne, Aube, Seine-et-Marne, Eure-et-Loir, Loiret and Yonne. The East periphery comprises the "départements" of Ardennes, HauteMarne, Meuse and Nièvre. Normandy is here defined as the Orne and Seine-Maritime "départements"

fodder crop such as clover, alfalfa, peas or horse beans. This new agrarian system, which did not involved a significant change in either farm size or the structure of the landscape, allowed a considerable increase in livestock density and hence in manure availability and cereal yield (Fig. 3d; Table 3). The potential for commercial export nearly reached $400 \mathrm{~kg} \mathrm{~N} / \mathrm{km}^{2} /$ year, making this agrarian system more autotrophic than any that preceded it.

This system characterized the nineteenth and the first half of the twentieth century. Then, following the discovery of the industrial process of atmospheric nitrogen fixation by Fritz Haber and Carl Bosch in 1910, the transition to modern, mechanized agriculture, based on synthetic fertilizers began. The land area exploited by the average farmer increased by a factor of ten, with a yield per hectare increasing in similar proportion such that worker productivity increased by two orders of magnitude. At the same time, arable farming became entirely liberated from the previously obligatory link with animal husbandry. Depending on geographical or socio-cultural factors, some regions became able to specialize in large-scale crop farming, often exporting most of their production, while others turned to livestock breeding based on massive feed imports. The former is now the current practice in the central Paris basin, where rural territories, now largely devoid of livestock, have become dramatically autotrophic, with commercial export potentials of over $5,000 \mathrm{~kg} \mathrm{~N} / \mathrm{km}^{2} /$ year (Table 3; Figs. 3e, 4b). In contrast, the peripheral areas of the Paris basin turned to cattle breeding and fell in heterotrophy (see also Billen et al. 2007a; Mignolet et al. 2007). 


\section{The 'food-print' of Paris city}

By equating the food, feed, and firewood requirements of Paris to the potential for commercial export of agricultural products from the rural territory surrounding the city, we can estimate the area of the territory required to meet this urban demand. This area defines the extent of the imprint exerted by the city on the rural agricultural systems. Contrary to the concept of the 'ecological foot-print' as defined by Wakernagel and Rees (1996), our 'food-print' indicator only takes into account the area required for producing agricultural goods, and is expressed in terms of the effective surface of the surrounding territory, instead of using a normalized global-area unit.

Using (1) the Paris population sizes of Fig. 1, (2) the per capita $\mathrm{N}$ requirements of Table 2 , and (3) the potential for commercial export estimated in Table 3, the area of rural territory theoretically required to supply the city can be calculated (Fig. 5). Aside from the two demographic decrease periods of Paris in the fourteenth and sixteenth centuries, the results show an underlying increasing trend until the eighteenth century when the area reached around $60,000 \mathrm{~km}^{2}$; a value which corresponds to the size of the Seine watershed. This increase, however, is modest with respect to that of the urban population (Fig. 1). Despite a 50-fold increase in the population of Paris since the fifteenth century, the food-print of the city barely increased twofold. In contrast, the further doubling of the population in the twentieth century was paradoxically accompanied by a fivefold decrease in the food-print.

Our theoretical estimation for the area at the end of the eighteenth century can be validated by the results of the detailed analysis of Abad (2002). The author stresses that as early as the middle of the eighteenth century, the Parisian food market acted as very significant factor in the redistribution of financial resources throughout the entire kingdom but, despite this, the city imported most of its food from the adjacent provinces (Table 4) when these were expressed in nitrogen units. This represents a total area close to $60,000 \mathrm{~km}^{2}$. Most cereal products were obtained from the provinces of Ile-de-France, Brie-Champagne and Orléanais, most meat was derived from Normandy, Ile-de-France and Limousin and firewood was imported mainly through floating from the remote Morvan area in Bourgogne (Boissière 1991; Bruley 1995; Benoit et al. 2002, 2004) (Fig. 6). A clear specialization of these regions is thus already obvious in the nature of the commercially exported agricultural products, evoking, although in an octopus-like version, the concentric areas of von Thünen' model (1826). For those provinces that contributed most significantly, the calculated area-specific rate of $\mathrm{N}$ export, ranging from 10 to $97 \mathrm{~kg} \mathrm{~N} / \mathrm{km}^{2} /$ year (Table 4), is remarkably similar to our theoretical estimate of 60$150 \mathrm{~kg} \mathrm{~N} / \mathrm{km}^{2} /$ year at that time, particularly when it is considered that the export of these provinces was not only, even if mainly, destined to Paris. This is probably especially true for Picardie which exported its cereals to Flanders and beyond.

The recent and spectacular decrease in the Parisian foodprint observed since 1950 (Fig. 5) is another striking result provided by our analysis. The yields of modern agriculture as practised in the central regions of the Paris basin, often reaching $10,000 \mathrm{~kg}$ cereals/ha/year, are so high that they largely exceed the needs of Paris and are exported elsewhere, sometimes over very large distances. Table 5 illustrates this point by comparing the present urban food consumption, deduced from the data of Table 2 and the total population of the Paris conurbation, with the agricultural production of the rural areas of the Seine watershed, considered as the 'historical' supplying territory of Paris. Regarding most agricultural goods with the exception of meat and seafood, the Parisian basin produces
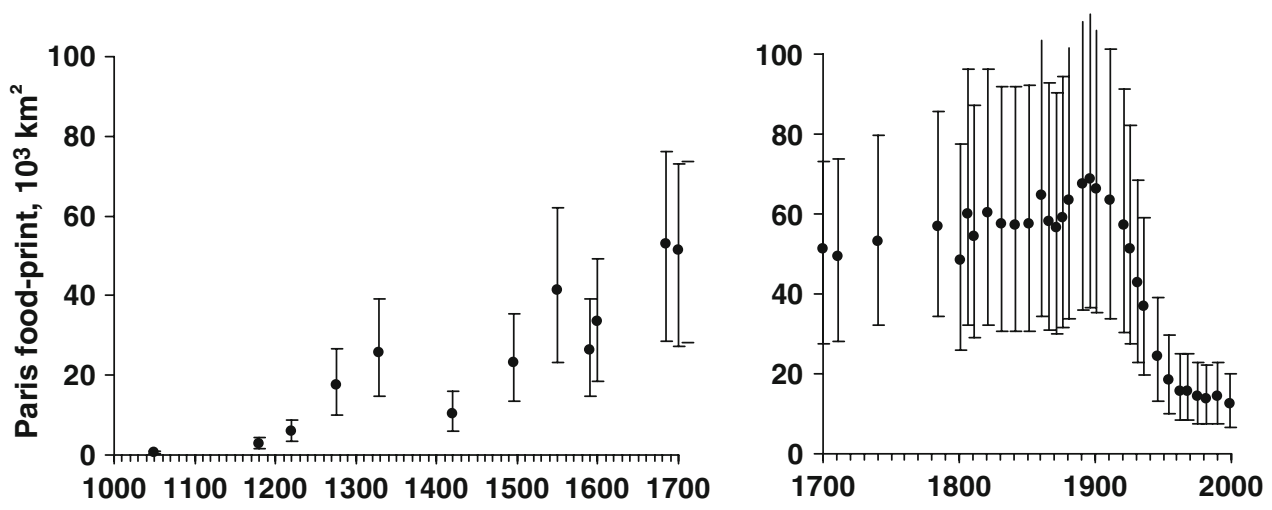

Fig. 5 The theoretical estimate of the area required to supply the food, feed and firewood requirements of Paris city during the last millennium. The area is obtained by dividing the $\mathrm{N}$ requirement of Paris (Fig. 1; Table 2) by the estimate of the potential for commercial export of $\mathrm{N}$ by the rural territory at the same period (Table 3). Error bars indicate the minimum and maximum estimates, given the uncertainty on per capita $\mathrm{N}$ requirement, and on the potential for commercial export from the rural area 


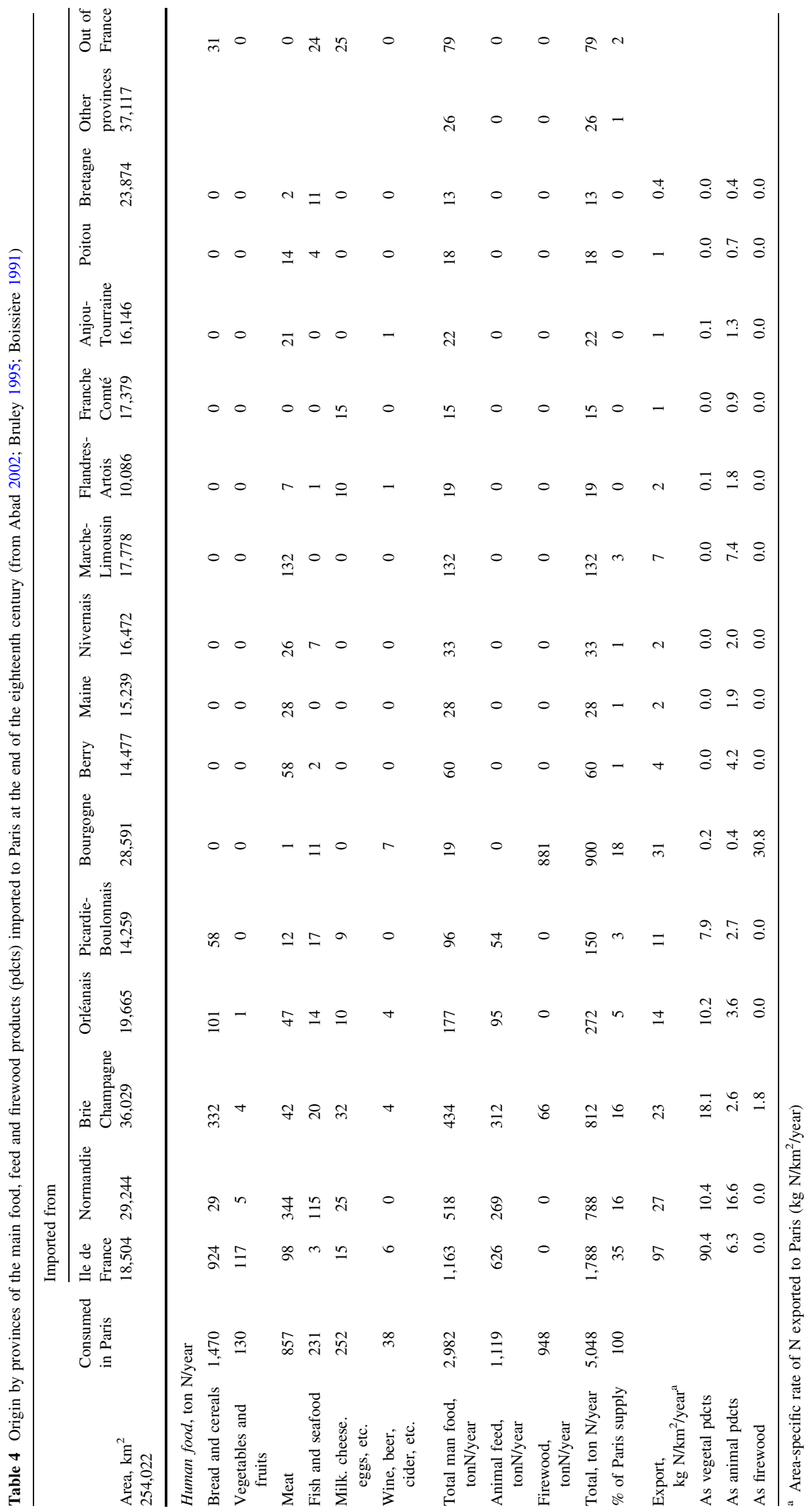


Fig. 6 a Contribution of the various provinces to the supply of food, feed and firewood to Paris at the end of the eighteenth century [calculated from the figures of Abad (2002) for food and feed and of Bruley (1995) for firewood]. b Areaspecific rate of commercial export of agricultural products from the provinces (in $\mathrm{kg} \mathrm{N}$ / $\mathrm{km}^{2} /$ year)

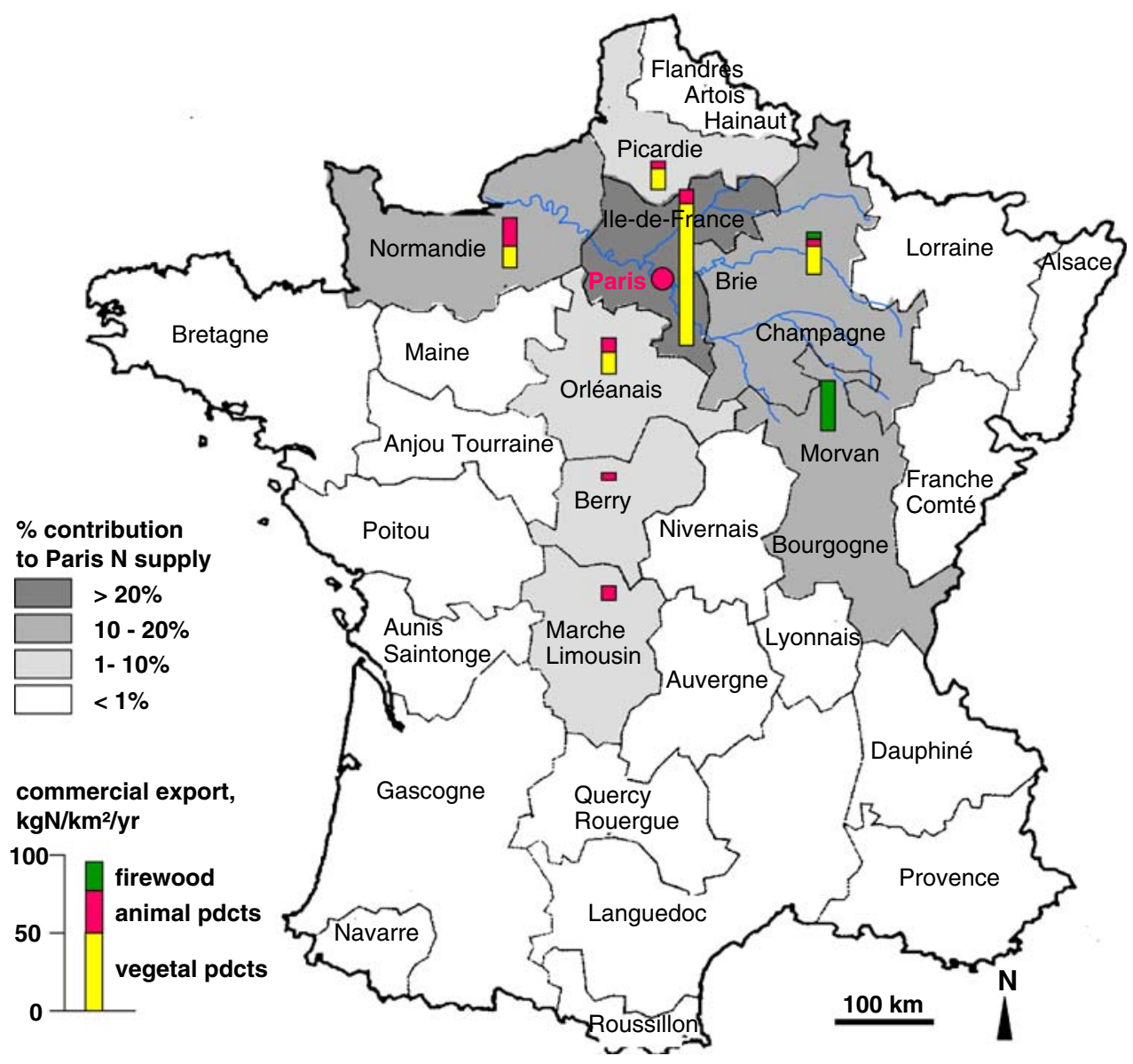

Table 5 Present (2000) consumption of agricultural goods by Paris conurbation (9,650,000 inhabitants) and corresponding production by the rural areas of the Seine watershed, expressed in terms of their nitrogen content (to be compared with Table 4, note that units here are ktonN/year)

\begin{tabular}{|c|c|c|c|c|}
\hline \multirow[b]{3}{*}{ Area, $\mathrm{km}^{2}$} & \multirow{3}{*}{$\begin{array}{l}\text { Consumed in } \\
\text { Paris conurbation }\end{array}$} & \multicolumn{3}{|l|}{ Production from } \\
\hline & & Central Paris basin ${ }^{\mathrm{a}}$ & Normandy ${ }^{b}$ & Eastern belt $^{\mathrm{c}}$ \\
\hline & & 52,657 & 17,929 & 18,257 \\
\hline \multicolumn{5}{|l|}{ Human food, ktonN/year } \\
\hline Bread and cereals & 13 & 263 & 43 & 39 \\
\hline Vegetables and fruits & 11 & 342 & 37 & 26 \\
\hline Meat & 29 & 7 & 7 & 3 \\
\hline Fish and seafood & 8 & - & - & - \\
\hline Milk, cheese, eggs, etc. & 18 & 7 & 9.68 & 2.85 \\
\hline Total, kton N/year & 78 & 619 & 96 & 72 \\
\hline$\%$ of Paris supply & 100 & 789 & 123 & 92 \\
\hline Potential export, $\mathrm{kg} \mathrm{N} / \mathrm{km}^{2} /$ year & & 11,597 & 5,155 & 3,209 \\
\hline As vegetal pdcts & & 11,401 & 4,350 & 2,914 \\
\hline As animal pdcts & & 196 & 805 & 295 \\
\hline
\end{tabular}

${ }^{a}$ Seine et Marne, Oise, Aisne, Marne, Aube, Yonne, Eure, Eure et Loir

b Orne, Calvados, Seine Maritime

c Ardennes, Haute Marne, Nièvre 
much more than is required to feed the city. On the other hand, examination of the available freight statistics for the Ile-de-France region (DREIF 2003) shows that, of the $14,000,000$ tons of agricultural goods entering the Paris conurbation by road, rail or waterway annually, more than $75 \%$ of which is derived from outside of the Seine watershed, as much as two-thirds are re-exported after processing (Barles 2007). It is therefore very difficult to assess the origin of the products internally consumed by the city, but it highlights that the present food market of Paris is extremely open and only loosely dependent upon products from the immediately surrounding regions.

\section{Conclusions}

The data gathered in this paper describe how the growth of the food requirements of Paris over one millennium have kept pace with the development of the commercial export potential of the surrounding rural territory. They show how closely the city and its hinterland have been linked together until the last 50 years. Paris developed at the confluence of the three major tributaries of the Seine River, at the centre of the watershed and in the middle of a large and fertile sedimentary basin. This territory constituted the natural hinterland of the city, from which it could obtain and transport within the walls most of the agricultural resources needed for its development during a period extending over more than the first nine centuries of the last millennium. On the other hand, in response to the growing urban demand, the rural areas evolved to focus on exportation and became specialized agrarian systems, making possible the development of Paris without the excessive extension of its supplying area, which remained largely contained within an area roughly corresponding to the Seine Basin. Clearly in this example, the long-term process of urbanization consisted of a mutual evolution of the rural and urban territories in their management of biogeochemical fluxes.

Only during the last 50 years has this close interaction apparently been disrupted. Due to the unprecedented increase in agricultural yields made possible by the general uptake of modern farming techniques, Paris ceased to constitute the main outlet for the agricultural products from the Paris basin. Currently, agriculture in this area is mostly driven by the logics of international markets rather by local urban demand, which today represents only one of many destinations for the agricultural products of the region. Conversely, the modern agrarian system now dominating the Parisian basin is extremely demanding in external resources such as fuel, chemical fertilizers and pesticides, and generates environmental dysfunctions in the form of water and, to a lesser extent, air pollution (ref. in Billen et al. 2007b). The increasing pressure placed on the rural territory for environmental resources other than space itself is not taken into account in our spatial assessment of the impact of Paris food requirements as defined here. This should be kept in mind when interpreting the calculated reduction in the food-print during the last 50 years (Fig. 5).

Indeed, contrary to the ecological footprint proposed by Wakernagel and Rees (1996), our spatial imprint calculation refers to the acreage of a "real" rural territory theoretically required to supply the food of a city with the current farming techniques. It does not consider a comprehensive account of all resources required, such as energy, fertilizers and waste disposal, converted into abstract and additive "global hectare equivalent" units. Although both approaches may be useful and complementary, we defend the idea that a closer look at how rural territories evolve in terms of their capacity for commercial export of nitrogen containing food products in response to the demand from local or distant urban markets might be a promising approach to understand the global issue of world food resource allocation in the context of increasing population sizes and urbanization.

Acknowledgments This work was undertaken in the framework of the PIREN-Seine programme launched by the CNRS and funded by several other institutions (especially the AESN-Agence de l'Eau Seine-Normandie-, the SIAAP-Syndicat Interdépartemental pour l'Assainissement de l'Agglomération Parisienne and the Ville de Paris), as well as in the scope of the PIRVE (CNRS-MEDAD) programme. Several meetings supported by ESF-(NinE), LOICZ, and UNESCO, as well as the ACI-FNS National Programme "Ecosphere Continentale (ECCO), contributed to the maturation of the approach.

Open Access This article is distributed under the terms of the Creative Commons Attribution Noncommercial License which permits any noncommercial use, distribution, and reproduction in any medium, provided the original author(s) and source are credited.

\section{References}

Abad R (2002) Le Grand Marché: l'approvisionnement de Paris sous l'Ancien Régime. Fayard, Paris, $1030 \mathrm{p}$

Asher F (2001) Les nouveaux principes de l'Urbanisme. La fin des villes n'est pas à l'ordre du jour. Editions de l'Aube, $104 \mathrm{p}$

Baccini P, Bruner P (1991) Metabolism of the anthroposphere. Springer, Berlin, p 169

Barles S (2005) L'invention du déchet urbain. Vallon C (ed), Seyssel, $297 \mathrm{p}$

Barles S (2007) Feeding the city: food consumption and flow of nitrogen, Paris, 1801-1914. Sci Total Environ 375:48-58. doi: 10.1016/j.scitotenv.2006.12.003

Barles S, Lestel L (2007) The nitrogen question: urbanisation, industrialisation and river quality in Paris (France), 1830-1939. J Urban Hist 33:794-812. doi:10.1177/0096144207301421

Benoit P, Berthier K, Billen G, Garnier J (2002) Agriculture et aménagement du paysage hydrologique dans le bassin de la Seine au XIV-XVe siècle. In: Burnouff J, Leveau PH (eds): Les fleuves aussi ont une histoire, Actes du Colloque PEVS-SEDD, 8-10 avril 2002, Aix-en-Provence 
Benoit P, Berthier K, Boet P, Rezé C (2004) Les aménagements hydrauliques liés au flottage du bois, leur impact sur le milieu fluvial, XVIe-XVIIIe siècles. In: Burnouf J, Leveau P (eds) Fleuves et marais, une histoire au croisement de la nature et de la culture. Paris, CTHS, pp 311-320

Billen G, Garnier J, Mouchel J-M, Silvestre M (2007a) The Seine System: introduction to a multidisciplinary approach of the functioning of a regional river system. Sci Total Environ 375:112. doi:10.1016/j.scitotenv.2006.12.001

Billen G, Garnier J, Némery J, Sebilo M, Sferratore A, Benoit P et al (2007b) A long term view of nutrient transfers through the Seine river continuum. Sci Total Environ 275:80-97. doi:10.1016/ j.scitotenv.2006.12.005

Bois G (1981) Crise du féodalisme, Paris, Presses de la Fondation nationales des sciences politiques, $410 \mathrm{p}$

Boissière J (1991) Marché du bois en ville en France à l'époque moderne: quelques remarques. In

Bruley J (1995) Les Gondoliers du Morvan. Editions de l'Armançon, Précy-sous-Thil (France), p 334

Contamine P, Bompaire M, Lebecq S, Sarrazin J-L (2003) L'économie médiévale, A. Colin, coll. U, Paris, 447 p

Croze M (1988) Tableaux démographiques. La population en France. Histoire et Géographie, INED-Insee, p 1988

Dupeux G (1981) Atlas historique de l'urbanisation en France (18111975). Éditions du CNRS, Paris, p 350

DREIF (Direction Régionale de l'Equipement Ile-de-France) (2003). Statistiques du frêt. http://www.ile-de-france.equipement.gouv.fr/

Favier J (1997) Paris, deux mille ans d'histoire. Fayard, Paris, 1007 p

Feugère E (1904) L'octroi de Paris, histoire et législation. Paris, 678 p

Fourquin G (1956) La population de la région parisienne aux environs de 1328. Moyen Age 62:63-91

Galloway JN, Schlessinger WH, Levy H, Michaels A, Schoor JJ (1995) Nitrogen fixation: anthropogenic enhancement-environmental response. Global Biogeochem Cycles 9:235-252. doi: 10.1029/95GB00158

Galloway JN, Cowling EB (2002) Reactive nitrogen and the world: 200 years of change. Ambio 31:64-71. doi:10.1639/0044-7447 (2002)031[0064:RNATWY]2.0.CO;2

Garnier J, Laroche L, Pinault S (2006) Determining the domestic specific loads of two wastewater plants of the Paris conurbation (France) with contrasted treatments: a step for exploring the effects of the application of the European Directive. Water Res 40:3257-3266. doi:10.1016/j.watres.2006.06.023

Goubert P (1982) Beauvais et le Beauvaisis de 1600 à 1730: contribution à l'histoire sociale de la France du XVIIe siècle, Paris, Ed. de l'EHESS, vol 2, 653 p

INSEE (1995) (Institut National de Statistique et des Etudes Economiques) Tableaux de L'Economie Française

INSEE (2000) (Institut National de Statistique et des Etudes Economiques) Tableaux de L'Economie Française
INSEE (2006) (Institut National de Statistique et des Etudes Economiques) Tableaux de L'Economie Française

Jacquart J (1974) La crise rurale en Ile-de-France, 1550-1670, Armand Colin, Paris, 795 p

Kaplan SL (1988) Les ventres de Paris. Pouvoir et approvisionnement dans la France d'Ancien Régime. Fayard, Paris, p 702

Le Thi Phuong Q, Billen G, Garnier J, Théry S, Fézard C, Chau Van M (2005) Nutrient (N, P) budgets for the Red River basin (Vietnam and China). Global Biogeochem Cycles 19:GB2022. doi:10.1029/2004GB002405

Levasseur E (1889) La population française, La population française: histoire de la population française avant 1789 et démographie de la France comparée à celle des autres nations au XIXe siècle Paris. Rousseau A (ed), Paris.

Mazoyer M, Roudart L (1998) Histoire des agricultures du monde. Du Néolithique à la crise contemporaine. Seuil, Paris, p 531

Mignolet C, Schott C, Benoît M (2007) Spatial dynamics of farming practices in the Seine basin: Methods for agronomic approaches on a regional scale. Sci Total Environ 375:13-32. doi: 10.1016/j.scitotenv.2006.12.004

Philippe R (1961) Une opération pilote: l'étude du ravitaillement de Paris au temps de Lavoisier. Ann Econ Soc Civilis 16(3):564568

Rezé C (2002) Les aménagements du réseau hydrographique du Morvan pour le flottage du bois, du XVIe au XVIIIe siècle. Mémoire de maîtrise d'archéologie; Université Paris I-PanthéonSorbonne, 2002, $61 \mathrm{p}$

Schmid-Neset TS (2005) Environmental imprint of human food consumption: Linköping, Sweden 1870-2000. Linköping Studies in Arts and Science, no. 333. Unitryck, Linköping

Servais P, Garnier J, Demarteau N, Brion N, Billen G (1999) Supply of organic matter and bacteria to aquatic ecosystems through wastewater effluents. Water Res 33:3521-3531. doi:10.1016/ S0043-1354(99)00056-1

Smil V (1999) Nitrogen in crop production: an account of global fluxes. Global Biogeochem Cycles 13:647-662. doi:10.1029/ 1999GB900015

Soltner D (2005) Les bases de la production végétale. Collection Sciences et Techniques Agricoles, Bressuire (France), p 466

Von Thünen JH (1826) Der isolierte Staat in Beziehung auf Landwirtschaft und National Oekonomie. In: Fischer G, Jena G (eds), Perthes, Hamburg

Wakernagel M, Rees W (1996) Our ecological footprint: reducing human impact on earth. $160 \mathrm{pp}$. New Society Publishers, Gabriola Island

Woronoff D (2002) Histoire de l'industrie en France. Seuil, Paris, p 664

WWF, World Widelife Fund (2002) Rapport Planète Vivante 2002. ISBN: 2-88085-256-0, Banson Publishers, Cambridge, $36 \mathrm{p}$ 